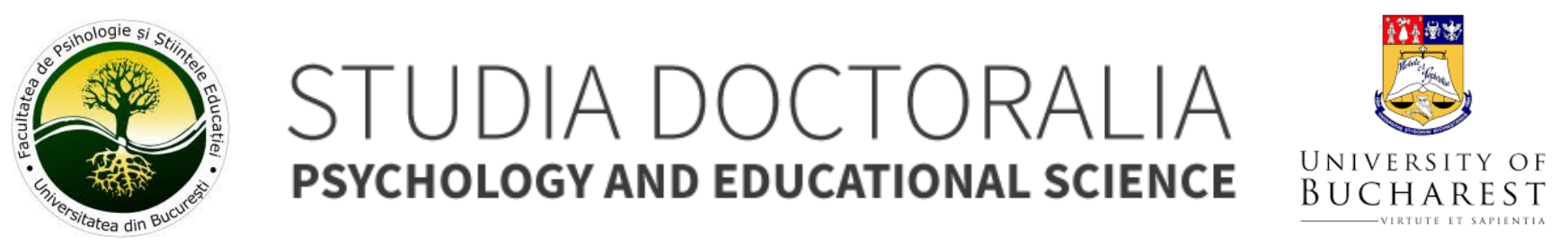

\title{
Determinants of work-family conflict in the context of the COVID-19 pandemic
}

\author{
Meryem Sedaroglu
}

University of Bucharest

\section{ARTICLE INFO}

Article history:

Received 20-April-2021

Accepted 28-April-2021

Available online 01-May-2021

This article should be cited as: Serdaroglu, M. (2021). Determinants of work-family conflict in the context of the COVID-19 pandemic. Studia Doctoralia. Psychology and Educational Science, 12(1), 20-34. https://doi.org/10.47040/sd0000086

This is an open access article under the CC BY license (http://creativecommons.org/licenses/by/4.0/).

Corresponding author at: University of Bucharest, Department of Psychology, 90 Panduri Av, Bucharest, RO.

Tel.: +40 (0) 31-425.34.45

E-mail address: serdaroglumeryem@gmail.com

\section{ABSTRACT}

In this paper, we want to investigate some determinants of work-family conflict. Factors related to job (job insecurity, job demands and resources, type of job, salary level, time spent at work, working conditions in the pandemic) and aspects such as fear of COVID-19 will be explored. The present study involved 301 people, aged between 18 and 65 years, $M=40.10, A S=8.25$. The instruments used were Work and Family Conflict Scale (Haslam et al., 2015), Job Insecurity Scale (De witte et al., 2000, 2010), The Job Demands-Resources Questionnaire (Bakker et al., 2014) and The Fear of COVID-19 Scale (Ahorsu et al., 2020). The results indicated that both job insecurity and workplace pressure are positive predictors of the work-family conflict, while autonomy is a negative predictor. Also, the moderating effect of fear of COVID-19 on the relationship between job insecurity and work-family conflict was analyzed, but it proved to be statistically insignificant. However, it was found that employees working from home during this period have a higher level of work-family conflict. Based on these results, work-family conflict management strategies can be developed, both individually and by organizations.

Keywords: work-family conflict, job insecurity, job demands and resources, teleworking, COVID-19

\section{INTRODUCTION}

\section{Work-family conflict}

Work-family conflict was recognized as a complex and multifaceted phenomenon by the researchers. The fact that it was approached by a wide variety of social sciences, including contributions from economics, management, sociology, and psychology (both from the perspective of organizational-industrial psychology and from the perspective of health psychology and family and couple psychology), demonstrates the importance of this construct. A person's career and family are two important components of their lives after they reach adulthood. The exploration of the interaction between work and personal life has grown in 
popularity through time, and maintaining a proper balance may be a never-ending challenge. Each of these aspects may be used to begin observing, investigating, and understanding significant parts of behavior or personality. Expectations at work and at home are not always congruent, resulting in some conflicts.

Greenhaus and Beutell (1985) described work-family conflict as a type of role conflict in which role constraints in the areas of work and family are contradictory in certain ways. As a result, either family life is restricted by workrelated activities or vice versa. According to Molina (2020), conflict can arise even on the basis of the initial hypothesis of collaboration between partners, such as when managing major family decisions (for example, whether a partner should accept a job or a promotion that would necessitate relocating the family) or simple, day-to-day decisions (such as who should leave work earlier to pick up the child from school). Thus, managing the work-family conflict is one of the major challenges in our current society.

\section{Theories on work-family conflict}

The role theory, which describes part of what the workfamily conflict implies, was one of the early efforts that formed the basis of the construct described above. First, according to role theory, work and family roles are set by others' expectations and what is deemed appropriate behavior for a certain role. In addition, both the work and the family environment involve multiple roles with multiple pressures on the person (Kahn et al., 1964). Many people submit to the role's expectations to reach various standards in their job and personal lives. When one of the job stressors is occurring, resource drain is inevitable. According to the resource drain theory, time, attention, and energy are finite resources (Edwards \& Rothbard, 2000). Furthermore, according to Duxbury et al. (1994), allocating work responsibilities to one partner while family responsibilities are assigned to the other is unreasonable and impractical, because both spouses have commitments in both areas at the same time. As a result of the permeability between the work and home environments, conflict between work and family is a typical occurrence. Recent research on workfamily conflict, on the other hand, is frequently based on boundary theory (Derks et al., 2014; Gadeyne et al., 2018). Because people have various responsibilities in the job and in their personal lives, they are regularly involved in the job crafting process, according to this hypothesis (Ashforth et al., 2000). In the context of work and family relationships, according to this theory, no person can have two different roles at the same time. The border theory, on the other hand, can offer us better understanding of the relationship between work and family in modern society (Clark, 2000). The concept of borders, much like the concept of boundaries, considers work and family as two distinct domains. Additionally, it underlines the impact that one domain has on the other. This theory seeks to identify the factors that generate work-family conflict and to create healthy and adaptive strategies to manage them in order to achieve a balance between work-related and family-related duties (Clark, 2000).

Thus, border theory wants to offer an explanation of the multidimensional interactions that occur between those who cross borders and their family and professional lives, to anticipate when conflict will develop, and to give a framework for reaching balance (Clark, 2000). Clark (2000) further adds that, though there are physical, temporal, and psychological barriers between work and family, these two domains of existence are closely intertwined. There has been increased worry in recent years about a possible decline in the quality of life at home (Tay et al., 2015). There are several explanations for this occurrence, including affluence, an increase in the number of single-parent families, privatization of family life, which is characterized by secluded living, and a lack of local resources and facilities. Furthermore, job pressures and demands, represented by extended working hours, which leads to increasing fatigue, leave far too little opportunity for quality time spent with family (Gregory \& Milner, 2009).

According to some researchers, blurring the lines between work and family can help people reduce conflicts between these two areas by providing flexibility in allocating role resources (Ashforth et al., 2000). Other academics, on the other hand, suggest that blurring the lines between work and family is a stressor that exacerbates conflict across domains since it can reduce the focus and energy committed to the role in which the person is now engaged (Glavin \& Schieman, 2012).

As a conclusion, this paper will be founded on Clark's (2000) border theory, as it attempts to investigate the determinants of work-family conflict, which might constitute "borders" in this sense. The attitude to be taken is that, though the two areas are distinct, they are tightly connected. In addition, for a better comprehension of the concept, the theoretical considerations outlined by Greenhaus and Beutell (1985) about the work-family conflict will be taken into account in this current study.

\section{Job insecurity}

Many authors define job insecurity as employees' expectations of continuing to work (Davy et al., 1997; Sverke et al., 2002; De Witte, 1999), whereas others define job insecurity as employees' perceptions of the probability of losing their jobs in moments of crisis (Mohr, 2000). Job insecurity is a major factor that affects the psychological health of employees (Inoue et al., 2018) and tends to diminish their motivation (Unsar, 2011). However, job insecurity implies uncertainty about the future, since employees are unsure if they will stay or lose their current position, or whether they should explore for new opportunities. A dismissed employee, on the other hand, knows for certain that he has lost his job and may thus 
prepare for the future. Researchers also point to the construct's involuntary character, implying a mismatch between what individuals want - the assurance of future employment and expected continuity - and what they actually receive - the risk of potential job loss (Flint et al., 2013).

Although this is a subjective interpretation rather than an objective reality, studies have been able to correlate experiences of job insecurity with a variety of negative consequences, including poor job performance, lower job satisfaction, and reduced levels of quality of life (Gilboa et. al., 2008; Jiang \& Probst, 2016; Wang et al., 2015). Furthermore, research suggests that job insecurity is evaluated by most individuals as worse as some objectively experienced events, such as job loss and unemployment (Kim \& von dem Knesebeck, 2015).

\section{Job Demands-Resources Model}

Demerouti et al. (2001) developed the Job DemandsResources Model to better understand the phenomena of burnout, a persistent condition of psychological stress at work characterized by (1) exhaustion, (2) mental detachment (cynicism, lack of excitement), and (3) low efficacy. Job demands are described as physical, social, or organizational factors that involve physical or mental effort and are connected with physiological or psychological consequences (Demerouti et al., 2001).

Instead, when we talk about job resources, we imply aspects that help employees in achieving their own goals while shielding them from physical and psychological harm and encouraging their personal growth and development (Xanthopoulou et al., 2009). Job resources promote job satisfaction and engagement. It is vital to recognize that each job has demands as well as resources, and the impact of both influence both the worker and the organization or corporation. In other words, the job demands and resources model's primary theoretical claim is that job demands are primarily responsible for the burnout phenomena, whereas resources predominantly determine well-being. Empirical research by Demerouti et al. (2001) validated the model. Schaufeli and Bakker (2004) proved that demands and resources are negatively associated, whereas demands are correlated to exhaustion. Furthermore, the impact of resources on exhaustion is less than that of demand. Moreover, important research in the fields of organizationalindustrial psychology and human resources has lately focused on job demands and resources as criteria for identifying work-family interactions, whether it is a conflict or a balance (Seery et al., 2008). Given that various responsibilities and expectations are deeply rooted in the contexts of work, community, culture, and family, it is crucial to understand the overall effect of resources and demands (Campione, 2008).

Similarly, according to Bakker et al. (2011), the job demands and resources model may indeed be successfully applied to the work-family interface, guiding us in recognizing the different characteristics of the workplace that might facilitate or discourage conflict from the two aspects of living.

\section{Job autonomy}

Until recently, two approaches to study job autonomy have been used: autonomous working groups and workplace attributes (Wall et al., 1986). The first grants autonomy to a complete team or organization and focuses on both a social and technical approach to job performance. The latter approach, on the other hand, emphasizes on the model of work characteristics and on each individual's autonomy (Hackman \& Oldham, 1976). Thus, Hackman and Oldham (1975) defined job autonomy as the level of flexibility, independence, and discretion that an individual has in carrying out work responsibilities. Job autonomy has been shown to improve organizational performance and job satisfaction. Work autonomy, particularly emotional dissonance, was thought by Morris and Feldman (1996) to be a key antecedent of emotional labor, since individuals with greater autonomy are able to disregard organizational policies when they clash with their personal feelings. As a result, they experience less emotional work than those who do not have this autonomy.

Berdicchia and Masino (2019) highlight the fact that autonomy is both a contextual characteristic of each job and a structural resource that employees may strive to increase mostly through job crafting. It should be noted that the two are not mutually exclusive, but both must be considered while attempting to analyze the construct. The authors also point out that levels of autonomy are also relevant, as more autonomy does not always mean higher performance, nor does it succeed in protecting employees from role conflicts. According to Bakker et al. (2005), job autonomy is the resource that most frequently serves as a barrier against demands with a high emotional strain. On the other side, Han et al. (2018) discovered that emotional work has a favorable influence on depressive mood among services and sales professionals. However, such effects are moderated by the job autonomy; the high degree of emotional work was associated with depressive mood only in the presence of low autonomy at work, in male employees.

Nevertheless, there is empirical evidence that autonomy in the workplace not only encourages individuals to attain their productivity objectives, but also their safety standards The more autonomy employees have in carrying out their tasks, the fewer negative incidents, accidents, and so forth. (Nahrgang et al., 2011).

\section{Work pressure}

Work pressure has not been precisely conceptualized, and there does not appear to be consensus on how it should be operationalized. According to Bakker et al. (2008), work pressure is a job demand that might predict burnout. 
However, based on an examination of the relevant theoretical studies, it appears that there is conceptual inconsistency about terms such as workload, time pressure, and work/job pressure. Roe and Zijlstra (2000) discovered that these terms are frequently used interchangeably. They continue by stating that work pressure is best understood as a subjective representation of a person's psychological and physiological state while performing professional activities.

Bowling and Kirkendall (2012), on the other hand, define work pressure as any characteristic of the amount or difficulty of tasks. Clearly, this variable is deemed flexible, and the pressure experienced may increase or decrease based on the worker's expectations of the quantity of work that remains to be done and his judgment of the opportunity to complete the job successfully. Work pressure appears to be a long-term concern that can even disrupt employees' free time. Bowling et al., (2015) indicate in their metaanalysis that work pressure is positively correlated with other job stressors, highlighting that the presence of these factors may signal that an organization is indifferent about its employees' well-being. Excessive workload, which is a source of stress at work, is correlated to other variables of this nature because they are all manifestations of management's lack of concern for people.

\section{Telework}

Telework is a kind of work that allows individuals to do their job from home (Dijst, 2004). Researchers who introduced the term for telecommuting defined it as an alternative to traffic congestion problems caused by everyday commuting as early as 1976. (Nilles et al., 1976). Also, time spent on the road, stress, and a desire for independence all contributed to the choice to popularize the telework phenomena. Home distractions and a lack of socializing at work, on the other hand, constitute deterrents (Mokhtarian \& Salomon, 1997). Over the years, numerous terms have been used to define the notion, including "telework," "flexible work," "distance work," "telecommuting", and "e-working". These terms refer to employees' capacity to work in a more dynamic way, in locations other than their regular workspaces, particularly at home, using technology to complete work duties (Grant et al., 2019). According to certain studies, telework can reduce the desire to leave a company while also increasing employee productivity, work engagement, and performance (Delanoeije \& Verbruggen, 2020). Teleworking has both positive and negative aspects. Mirchandani (2000), for example, claims that working from home causes worry and stress since those who select this choice must merge their professional and family lives. Moore (2006) shows that working from home does not improve the quality of life in terms of psychological well-being, subjective or objective, and states that employees who have young children are more stressed when working from home. The impact of this occurrence may also be influenced by the intensity of the experience and the characteristics of the job.
This paper looks at a different aspect of working from home, which has become the norm for many people around the world since the beginning of the coronavirus outbreak. Additionally, it is possible that for many people, working from home has been a completely new and unknown experience until now. Working from home, according to a survey conducted in Singapore, increases employees' stress levels even more, since they report significantly greater levels of stress than COVID-19 front-line professionals (Teo, 2020). Likewise, in India, this phenomenon of work from home has caused $67 \%$ to suffer from insomnia, particularly during quarantine, and the lack of housekeepers to assist with household chores has resulted in full management of all such activities while working (Times of India, 2020). Employees in Hong Kong, as well as those in Singapore and India, proved to experience more stress, job insecurity, felt anxious, lonely, burned out.

As a conclusion, in this context, it is possible to say that the decision to suspend office work was made promptly, but without any instructions on how to do so. According to Vyas and Butakhieo (2020), proper staff training is required if this practice is to become a viable alternative or a new standard in terms of work.

\section{Fear of COVID-19}

It is known that fear is an adaptive response in the presence of perceived dangers. However, when the threat is uncertain and continuous, as in the current coronavirus pandemic (COVID-19), fear can become maladaptive (Mertens et al., 2020). This is undoubtedly a stressful event, the consequences of which are already visible in the daily lives of people and organizations. It is an incident that involves, first and foremost, the reconstruction of one's personal and social life, as well as the educational system and routines, and also the work roles, with the chance of getting the virus thrown in for good measure. This completely unexpected pandemic condition, as well as COVID-19 fear, has a significant impact on psychological well-being, which has been correlated to a lower quality of life (Alyami et al., 2021).

Fear can enable safety behaviors (e.g., hand washing) to be triggered in response to threats (e.g., contamination), but it can also spread anxiety (e.g., contamination concerns and health anxiety) (Engelhard et al., 2015). COVID-19's debut, as well as the fact that it is global, has undoubtedly exacerbated people's worries, leading to stigmatization in some of the cases (Lin, 2020). Fear is a feature of infectious diseases that distinguishes them from other medical disorders. Fear has a direct relationship with transmission rate, as well as morbidity and death. According to a study that looked into the effects of infectious diseases, this can lead to other psychosocial issues such as stigma, prejudice, and mortality (Pappas et al., 2009). The COVID-19 pandemic continues to be a serious global problem that affects every aspect of life and disrupts society itself 
According to Coelho et al. (2020) COVID-19 is a situation capable of causing more fears (eg fear of contamination, future, financial instability, xenophobia and agoraphobia) and triggering elements related to anxiety and fear (similar to those present in specific phobias). Fear is normally avoided, although, like pain or hunger, it can be adaptive in the face of impending dangers. Anxiety can be adaptive in dealing with possible risks, but it can also be damaging, both individually and socially, if it is not well adjusted to the real threat (Mertens et al., 2020). When confronted with COVID19 , most people may not be able to think properly or rationally due to their fear.

The relationship between work-family conflict, job insecurity and fear of COVID-19

Job insecurity is an anticipated stress factor that is particularly prevalent during economic recessions and periods of precariousness in the job market (Keim et al., 2014). This can lead to tensions and worries about the future, which can exacerbate work and family conflicts (Höge et al., 2015).

According to the International Finance Corporation (2020), the COVID-19 pandemic caused a major economic crisis, which was felt in several regions of the world, but especially in Europe and Asia. Isolation measures (i.e. social distancing, self-isolation, travel restrictions, etc.) adopted to control the spread of COVID-19 have led to a reduction in the workforce in many economic sectors (Nicola et al., 2020), as well as a general perception of job insecurity (Spurk \& Straub, 2020). It has been found that perceived job insecurity is currently a major stressor (Hamouche, 2020), as the pandemic itself poses a high risk of financial loss (Zhou et al., 2020). Job insecurity can also increase concerns within a family, such as how to properly care for family members in the event of job loss, which can exacerbate the effects of the family-work conflict. Concerns about job insecurity focus both on the financial constraints of job loss and on the loss of latent employment benefits, such as social contacts and social status (Vander Elst et al., 2015). As a result, past research shows that job insecurity can lead to emotional breakdowns that have a negative impact on family life (Menaghan, 1991). Other study in this area reveals that job insecurity and role conflict, such as work-family conflict, have a positive correlation (Cooklin et al., 2015; Keim et al., 2014; Nauman et al., 2020).

Therefore, in view of the above, the first hypotheses of the study are established:

$\mathrm{H1}$ : Job insecurity is a significant positive predictor of work-family conflict.

$\mathrm{H} 2$ : The relationship between job insecurity and workfamily conflict is moderated by fear of COVID-19.

The relationship between work-family conflict and job autonomy
Job autonomy is a valuable resource that can provide employees with a variety of benefits in both the professional and personal areas. Previous study has shown that job autonomy increases motivation to complete tasks, enhancing employee engagement and productivity (Bakker \& Demerouti 2007). Job autonomy, in addition to its principal function, can act as a buffer against the negative impacts of job demands by giving employees additional opportunities and resources to cope with (Brauchli et al., 2014).

Brauchli et al. (2014) found that job autonomy mediated the link between work-family conflict and many job-related dimensions, such as satisfaction, intention to leave the company, and organizational commitment, using data from four major Swiss companies.

Job autonomy, based on the job demands and resources model, assists employees in reducing workplace tensions caused by opposing duties in their work and personal lives (Korunka \& Kubicek, 2017). Many people who have the ability to choose their working hours, for example, are more able to integrate work and family commitments.

Thus, the following hypothesis of the study is:

$\mathrm{H} 3$ : Autonomy is a significant negative predictor of work-family conflict.

\section{The relationship between work-family conflict and work pressure}

Work pressure has been recognized as a job demand that should not be overlooked, as it is a critical predictor of work-family conflict in prior study (Bakker et al., 2011). Job demands, as previously stated, refer to the physical, psychological, social, or organizational aspects of a job that necessitate physical or psychological effort or skills and are associated to physiological or psychological expenses (Bakker et al., 2005). Although job demands may not always have a negative impact, they can be a source of stress if achieving them involves a great deal of effort. Recent research has shown that job demands, such as work pressure and high workload, have been strongly associated with work-family conflict (Balogun et al., 2020). Thus, we would expect employees who feel overwhelmed by their demands at work and who perceive their jobs to be demanding in terms of time or volume of tasks will also experience higher levels of work-family conflict.

$\mathrm{H} 4$ : Work pressure is a significant positive predictor of work-family conflict.

\section{The relationship between working conditions and work-family conflict}

Because of the coronavirus pandemic, the work office was shifted to the employees' homes, which was a completely new experience for many of them. Prior to the pandemic, working from home was more of a reward provided by employers because it involved flexibility, convenience, and comfort. Many employees, however, are 
suddenly faced with this new reality, and the majority were unaware of this possibility of working. Additionally, studies show that while working from home has some advantages, such as a lower likelihood of leaving the company, higher employee productivity, work commitment, better performance, (Delanoeije \& Verbruggen, 2020), it also has certain disadvantages. Purwanto et al. (2020), for example, point out some of the more concrete downsides of the scenario, such as the fact that individuals working from home are responsible for their own utilities and internet costs. However, most studies also emphasize that employees working at home may be interrupted by young children or other family members (Kazekami, 2020), and the blurred lines between work and family life add to work stress (Grant et al., 2019). Similarly, Eddleston and Mulki (2017) found that working from home corresponds with employees' failure to break away from tasks received throughout the day after the working program ended. It was also recently

\section{METHODOLOGY}

\section{Participants and procedure}

The present study involved 301 people, aged between 18 and 65 years, $M=40.10, S D=8.25$. They were recruited online, using the snowball sampling. The form with the questionnaires of this study was distributed on social networks, with the specification to be forwarded. Of the respondents, 100 are male (33.22\%) and 201 are female (66.8\%), 243 are married (80.73\%), 27 are in a relationship $(8.97 \%)$ and 31 are single (10.3\% ). Regarding the hours spent at work, 46 people declare that they spend less than 6 hours (15.26\%), 108 declare that they spend between 6 and 8 hours (35.88\%) and 148 declare that they spend more than 8 hours (48.86\%), 67 they have a salary level between 1,000 and 3,000 lei $(22.26 \%), 127$ have a salary level between 3,000 and 6,000 lei (42.19\%), and 108 have a salary level of over 6,000 lei (35.55\%). Regarding working conditions, 92 people work from home (30.57\%), 105 work from office (34.88\%), and 105 work from home and office (34.55\%), 106 people are in management positions (35.22\%) and 196 are in executive positions (64.78\%). It should be mentioned that all participants stated that they have children.

The data were collected between November 2020 and February 2021, and the answers were stored using Google Forms, respectively Google Drive, being measured only the constructs targeted by this study. The participants were recruited online, so the form was distributed on social networks such as Facebook, WhatsApp and Instagram, with the request to be passed on to other people who meet the criteria of the study (to have a job and to have children). They had to go through a set of self-report questionnaires, as well as answering questions about: gender, age, marital discovered that the benefits of telework, which have been stated in the literature throughout time, may only be meaningful and applicable to individuals who are able to fully engage in their work, whether it takes place in the office or not (Kaduk et al., 2019). Therefore, in a context such as the current pandemic, in which teleworking is no longer a voluntary choice, but rather an imposed situation, which is not related to the employee, it is necessary to look at the issue from a multilateral perspective.

As a result of the obligation to comply with the rules of social distancing, more employees began working from home in mid-March 2020, this significant change in job and domestic borders can be presumed to have produced significant role conflict disturbances. Thus, the following hypothesis of the study is:

$\mathrm{H} 5$ : Employees who work from home during this period have a higher level of work-family conflict than employees who work from the office or from both places.

status, income level, time spent at work, type of position held and conditions working in a pandemic (from home, office or both). Respondents were informed about the anonymity of the data and that they can withdraw from the study at any time, without any negative consequences, and were then asked to confirm that they agreed to participate in the study. It was not necessary to delete any of the responses received, as they all met the necessary conditions.

\section{Instruments}

Work-Family conflict was measured using the Work and Family Conflict Scale (Haslam et al., 2015). The scale was designed to be applied to parents. It contains 10 items and includes two subscales: interference of work with the family (from item 1 to item 5) and interference of the family with work (from item 6 to item 10). The answers are given on a 7-step Likert scale, where $1=$ strong disagreement and 7 = strong agreement. Examples of items are: "My work has a negative impact on my family life", "Working often makes me irritable or short tempered at home".

Job insecurity was measured with the Global Qualitative Job Insecurity Scale and Quantitative Job Insecurity Scale (De witte et al., 2000, 2010). Taking into account the authors' statements that qualitative job insecurity is as detrimental to psychological well-being as quantitative job insecurity, both scales were used, as we are aiming for a comprehensive analysis. Answers are given on a 5-step Likert scale where $1=$ strong disagreement and 5 = strong agreement. Examples of items are: "I think my job will change for the worse", "I will probably lose my job soon".

Job autonomy as well as work pressure were measured with The Job Demands-Resources Questionnaire (Bakker et al., 2014). The questionnaire captures several 
dimensions, both in terms of job demands and resources, but in the present paper only the items targeting the variables mentioned were used. The subscale that measures autonomy contains three items, and the one that targets work pressure four items, both subscales being built on a 5-step Likert scale, where 1 = never, and 5 = very often. Examples of items are: "I have flexibility in doing my job", "I have to work fast".
Fear of COVID-19 was measured using The Fear of COVID-19 Scale (Ahorsu et al., 2020). It contains seven items, and the answers are given on a 5-step Likert scale where 1 = strong disagreement and 5 = strong agreement. Examples of items are: "I am very afraid of coronavirus-19", "It makes me uncomfortable to think about coronavirus-19".

\section{RESULTS}

\section{Descriptive statistics}

Table 1. Descriptive statistics

\begin{tabular}{|c|c|c|c|c|c|c|c|c|}
\hline & $M$ & SD & $a$ & $\mathrm{Jl}$ & FCO & $\mathrm{JA}$ & WP & WFC \\
\hline$\overline{\mathrm{JI}}$ & 19.05 & 7.03 & .84 & 1 & & & & \\
\hline $\mathrm{FCO}$ & 15.80 & 6.49 & .89 & $.37^{\star *}$ & 1 & & & \\
\hline $\mathrm{JA}$ & 11.31 & 3.34 & .85 & $-.34^{* *}$ & $-.30^{* *}$ & 1 & & \\
\hline WP & 14.18 & 4.20 & .87 & $.31^{* *}$ & $.23^{* *}$ & $-.23^{* \star}$ & 1 & \\
\hline WFC & 29.50 & 14.23 & .94 & $.53^{* *}$ & $.45^{\text {*k }}$ & $-.44^{* *}$ & $.60^{* *}$ & 1 \\
\hline
\end{tabular}

$\mathrm{JI}$ - Job insecurity, FCO - Fear of COVID-19, JA - Job autonomy, WP - Work pressure, WFC - Work-family conflict.

\section{Hypothesis testing}

$\mathrm{H} 1$. Job insecurity is a significant positive predictor of workfamily conflict.
To test this hypothesis, a simple linear regression analysis was performed, having as predictor job insecurity and as a dependent variable the work-family conflict.

Table 2. Simple linear regression analysis for job insecurity as a predictor of work-family conflict

\begin{tabular}{rcccccc}
\hline & $\mathrm{R}^{2}$ & $\mathrm{~B}$ & $\mathrm{SE}$ & Beta & $\mathrm{t}$ & $\mathrm{p}$ \\
\hline Job Insecurity & .28 & 1.08 & .10 & .53 & 10.87 & .00 \\
\hline
\end{tabular}

It is observed that job insecurity is responsible for $28 \%$ of the variation of the work-family conflict, the regression equation being statistically significant, $F(1,300)=118.23, p<.01$. Job insecurity is a significant positive predictor of work-family conflict, $\beta=.53, p<.01$. Considering this result, we can say that the $\mathrm{H} 1$ hypothesis is supported by the analyzed data.
$\mathrm{H} 2$. The relationship between job insecurity and work-family conflict is moderated by fear of COVID-19.

In order to test this hypothesis, a moderation analysis was performed, having job insecurity as predictor, work-family conflict as a dependent variable, and fear of COVID-19 as a moderating variable.

Table 3. Moderation analysis for fear of COVID-19 in the relationship between job insecurity and work-family conflict

\begin{tabular}{|c|c|c|c|c|c|c|}
\hline & \multirow[b]{2}{*}{ Estimate } & \multirow[b]{2}{*}{ ES } & \multicolumn{2}{|c|}{$95 \% \mathrm{Cl}$} & \multirow[b]{2}{*}{ Z } & \multirow[b]{2}{*}{$\mathrm{p}$} \\
\hline & & & Lower & Upper & & \\
\hline Jl. Job insecurity & .85 & .10 & .66 & 1.03 & 8.7 & .00 \\
\hline Fear of COVID-19 & .62 & .10 & .41 & .81 & 6.09 & .00 \\
\hline $\mathrm{Jl} *$ Fear of Covid-19 & .01 & .01 & -.01 & .03 & .73 & .47 \\
\hline
\end{tabular}


It is observed that the fear of COVID-19 fails to moderate the relationship between job insecurity and work-family conflict, the moderation estimate being $.01, \mathrm{Cl} 95 \%(-.01, .03), \mathrm{Z}=$ $.73, p>.05$.

Taking into account this result we can say that the $\mathrm{H} 2$ hypothesis is not supported by the analyzed data.
H3: Autonomy is a significant negative predictor of workfamily conflict.

In order to test this hypothesis, a simple linear regression analysis was performed having as predictor autonomy at work and as a dependent variable the work-family conflict.

Table 4. Simple linear regression analysis for job autonomy as a predictor of work-family conflict

\begin{tabular}{ccccccc}
\hline & $\mathrm{R}^{2}$ & $\mathrm{~B}$ & $\mathrm{SE}$ & $\mathrm{Beta}$ & $\mathrm{t}$ & $\mathrm{p}$ \\
\hline Job Autonomy & .19 & -1.86 & .22 & -.44 & -8.40 & .00 \\
\hline
\end{tabular}

It is observed that job autonomy is responsible for $19 \%$ of the variation of the work-family conflict, the regression equation being statistically significant, $F(1,300)=70.61, p$ $<.01$. Job autonomy is a significant negative predictor of work-family conflict, $\beta=-.44, p<.01$.

Considering this result, we can say that the $\mathrm{H} 3$ hypothesis is supported by the analyzed data.
$\mathrm{H} 4$ : Work pressure is a significant positive predictor of workfamily conflict.

In order to test this hypothesis, a simple linear regression analysis was performed having as predictor the perceived pressure at work and as a dependent variable the workfamily conflict.

Table 5. Simple linear regression analysis for work pressure as a predictor of work-family conflict

\begin{tabular}{rcccccc}
\hline & $\mathrm{R}^{2}$ & $\mathrm{~B}$ & $\mathrm{ES}$ & $\mathrm{Beta}$ & $\mathrm{t}$ & $\mathrm{p}$ \\
\hline Work Pressure & .36 & 2.04 & .16 & .60 & 13.09 & .00 \\
\hline
\end{tabular}

It is observed that work pressure is responsible for $36 \%$ of the variation of the work-family conflict, the regression equation being statistically significant, $F(1,300)=171.34, p$ $<.01$. Work pressure is a significant positive predictor of work-family conflict, $\beta=.60, p<.01$.

Considering this result, we can say that the $\mathrm{H} 4$ hypothesis is supported by the analyzed data.
H5: Employees who work from home during this period have a higher level of work-family conflict than employees who work from the office or from both places.

To test this hypothesis, a one-way ANOVA analysis of variance was performed.

Table 6. Mean scores for work-family conflict depending on working conditions

\begin{tabular}{lcccccc}
\hline & & & & & \multicolumn{2}{c}{$95 \% \mathrm{Cl}$} \\
\cline { 5 - 7 } & $\mathrm{N}$ & $\mathrm{M}$ & $\mathrm{SD}$ & $\mathrm{SE}$ & Lower & Upper \\
\hline Home & 92 & 34.17 & 15.36 & 1.60 & 30.99 & 37.36 \\
Office & 105 & 27.62 & 13.84 & 1.35 & 24.94 & 30.30 \\
Both & 105 & 27.28 & 12.67 & 1.24 & 24.82 & 29.73 \\
Total & 302 & 29.50 & 14.23 & .82 & 27.88 & 31.11 \\
\hline
\end{tabular}

Table 7. One-way ANOVA for differences in work-family conflict depending on working condition

\begin{tabular}{|c|c|c|c|c|c|}
\hline & Sum of Squares & $\mathrm{df}$ & Mean Square & $\bar{F}$ & Sig. \\
\hline Between groups & 2900.53 & 2 & 1450.26 & 7.47 & .00 \\
\hline Within group & 58084.97 & 299 & 194.26 & & \\
\hline Total & 60985.50 & 301 & & & \\
\hline
\end{tabular}




\begin{tabular}{llccccc}
\hline & & Mean Difference & & & \multicolumn{2}{c}{$95 \% \mathrm{Cl}$} \\
\cline { 6 - 7 } (I) Working conditions & (J) Working conditions & $(\mathrm{I}-\mathrm{J})$ & Std. Error & Sig. & Lower & Upper \\
\hline Home & Office & 6.56 & 1.99 & .00 & 1.76 & 11.35 \\
& Both & 6.90 & 1.99 & .00 & 2.11 & 11.69 \\
\hline
\end{tabular}

It is observed that there are statistically significant differences in terms of work-family conflict depending on working conditions, $F(2,299)=7.47, p<.01$, in the sense that people working from home have higher levels of this type of conflict $M=34.17, S D=15.36$, while the people working in the office register $M=27.62, S D=13.84$, and those working in both places register $\mathrm{M}=27.28, \mathrm{SD}=12.67$. For more accurate identification of differences, the Bonferroni post-hoc test for multiple differences was

\section{DISCUSSION}

First of all, the present study is a cross-sectional, descriptive, correlational and differential one, and its results come from the data obtained from a group of 301 participants, all employees and, at the same time, parents. It is noticed that participants' scores in job insecurity and fear of COVID-19 are relatively low, while their scores in autonomy and work pressure are high. In terms of the study's dependent variable, work-family conflict, the scores were average. Hypothesis $\mathrm{H} 1$ showed that job insecurity is a significant positive predictor of work-family conflict. If there is a significant chance of losing a job, there will be negative implications in all major aspects of life, not just the individual level. It may be assumed that because of the additional stressors that the threat of losing a job presents, there may be greater tension in the household and among colleagues at work, and therefore the work-family conflict may intensify. This finding is consistent with prior research, which has found links between job insecurity and role conflict, particularly work-family conflict (Cooklin et al., 2015; Keim et al.,. 2014; Nauman et al. , 2020).

It is well known that uncertainty is a stress factor that can lead to maladaptive and counterproductive actions but, additionally, job uncertainty could be a direct danger to the family's source of income. Although not analyzed separately, in this study job insecurity involved two parts: quantitative (which relates rather to the strictly pragmatic aspects of this psychological construct) and qualitative (which refers specifically to the value attributed to work).

The $\mathrm{H} 2$ hypothesis was not supported by the analyzed data, so the fear of COVID-19 fails to moderate the relationship between job insecurity and work-family conflict. Although not specifically investigated in current research, it is very likely that a variety of variables, such as, for example, performed, noting that the highest difference is found between people working from home and people working in a mixed system, $\mathrm{DM}=6.90, \mathrm{Cl} 95 \%(2.11,11.69), \mathrm{p}<.01$, followed by the difference between persons working from home and persons working from their office, $\mathrm{DM}=6.56$, CI95\% (1.76, 11.35), $p<.01$.

Considering these results we can say that the $\mathrm{H} 5$ hypothesis is supported by the analyzed data.

resilience to crisis situations or the ability to take risks, play a more important role than we would assume. Also, although it is possible that drastic safety measures, such as the lockdown from March to April 2020, have exacerbated the fear of COVID-19, the period in which the data were collected does not correspond to this (the data were collected between November 2020 and December 2021), and this could explain the results. However, no conclusive explanation can be given regarding the $\mathrm{H} 2$ hypothesis.

Job autonomy is a significant negative predictor of workfamily conflict, according to hypothesis $\mathrm{H} 3$, which is consistent with earlier research. Korunka and Kubicek (2017) discovered, for example, that job autonomy, based on the job demands and resources model, helps individuals minimize the tensions produced by conflicting responsibilities in their professional and personal life. It is well recognized that autonomy at work is a resource, and studies have identified job autonomy as a quality that can lead to favorable results (Lu et al., 2017), which is confirmed in the current situation.

It can be anticipated that a high degree of autonomy will always provide a sense of control over activities at work, and that in the event of situations of conflict, whether at work or in the family, autonomy will provide the employees the support they need to deal with conflicts. Given that autonomy includes making decisions about one's own job, it can be argued to be advantageous in balancing the two realms of life, work and family.

Hypothesis $\mathrm{H} 4$ showed that workplace pressure is a significant positive predictor of work-family conflict, a result that is in line with the results of previous studies in the literature. For example, Balogun et al. (2020) showed that job demands, such as work pressure and workload, were strongly associated with the work-family conflict. We can 
suppose that an unstable job market climate, such as the one in present, which may be defined as far too demanding, as a result of the pandemic setting, adds to employees feelings of strain and pressure, resulting in considerable conflicts between work and family.

Besides that, employees, who are most likely stressed by a lack of time and the volume of tasks assigned to them, struggle to spend enough quality time with their families, and it is even possible for them to neglect their families as a result of the commitments made, which explains the results of hypothesis $\mathrm{H} 4$.

Hypothesis $\mathrm{H} 5$ indicated that employees working from home during this period have a higher level of work-family conflict than employees working from their office or from both places. This phenomena can be explained by the fact that when working from home, employees may encounter an increase in family responsibilities, and in order to minimize the tension caused by the work-family conflict, they must establish constant boundaries and agreements with their families. This is challenging, especially in the present pandemic situation, where schools and kindergartens are closed, increasing the risk of job interruptions caused by young children. In such a situation, proper management requires taking into account factors such as the roles that the partners will share with each other in terms of childcare, family chores, time given to work or family, and space delimitation. As these were not explored in the present study, they may, however, be a source of conflict for employees working from home.

As a result, it is reasonable to expect that interruptions and disruptions during working hours, as well as uncertainty and ambiguity about the borders between the two domains of life, can amplify the tensions created by the work-family conflict. Likewise, the person may experience confusion and role conflict, not knowing when it is appropriate to adopt the role of a parent or employee.

Also, whereas before the pandemic, many chose to work from home for convenience and more flexibility in their job, they did so during this period because they were required to. This can greatly change the dynamics behind the workfamily conflict, especially in the context in which for many, teleworking is very possible to be a completely new experience. However, for those who worked from home prior to the pandemic, it is a new and completely different occurence, as their work space is suddenly disrupted by other family members, and they are the only people the worker interacts with, making his social circle much smaller than before, in a period full of worries and fears. Furthermore, we do not know how companies aided work from home because, as prior research has shown, employees depend on the organization when it comes to successfully using such work alternatives (Abendroth \& Reimann, 2018).
Therefore, the results of the $\mathrm{H} 5$ hypothesis are similar to those of previous studies. In this regard, for example, Kazekami (2020) notes that employees can be easily interrupted when working at home by young children or other family members, and Grant et al. (2019) mentions that the blurred boundaries (physical, temporal and psychological) between work and family life, caused by telework, also contribute to the pressure felt during work.

\section{Conclusions}

The results obtained were analyzed and interpreted through the prism of border theory (Clark, 2000) which argues that although there are physical, temporal and psychological borders between work and family, these two domains of life are interconnected. The author also mentions that in order to strike a balance between work-related and family-related responsibilities, it is necessary to predict what triggers this conflict, and therefore this study aimed to investigate the factors that determine work-family conflict, so that the adaptive modalities of its management can be established later.

The present study draws attention to the influence of perceived job insecurity on the work-family conflict, and therefore it can be said that the first variable has a stressful role on both professional and personal life, which is consistent with the results of previous studies. Although fear of COVID-19 has no moderating effect on the relationship between job insecurity and work-family conflict, it is important to note that even in a crisis situation such as this, no significant psychological factors were taken into account (resilience, for example).

The following hypotheses are based on Demerouti et al. (2011)'s model of job demands and resources and found that both autonomy and pressure significantly influence work-family conflict. Autonomy, being a resource of the job, is a negative predictor, which leads us to believe that having freedom at work is a benefit and the first step towards achieving a possible balance between professional and personal life. On the other hand, pressure, a job requirement, is a positive predictor of work-family conflict, which is, again, in line with previous studies in the literature.

This study also found that employees who worked from home during the pandemic had higher levels of work-family conflict, and, starting from the border theory (Clark, 2000), it can be said that that these results may be due to the phenomenon of blurring the borders between the two areas.

\section{Practical implications}

The current study captures major themes such as workfamily conflict, telework, job demands and resources, job insecurity, and the current pandemic context, which is so prevalent in everyone's lives. These aspects are fundamental, first and foremost from the standpoint of organizational-industrial psychology and the field of human resources, because they can determine the search and 
establish a proactive approach for better management of people in the company or organization, particularly in such difficult times. In a context like the current one, where teleworking is no longer a voluntary choice but rather an imposed situation, HR specialists and consultants must make decisions and initiate initiatives that are feasible for both employers and employees, as there are implications for both parties in both directions. Employees, for example, can protect themselves from the potentially detrimental repercussions of excessive job demands by using job resources, while, by doing so, they may also become more easily motivated.

At the same time, with increasing work demands, it is difficult for many people to keep up with family responsibilities, but understanding the factors contributing to work-family conflict helps to prevent it and, potentially, find a balance between the two fields of life with the help of adaptive approaches. However, in order to preserve a positive work environment, organizations must also find a solution (for example, team-building events or the possibility to utilize job crafting). Additionally, it would be beneficial for company managers to attempt to adjust their leadership style to these concerns.

Many employees may be exposed to telework for the first time while still isolated from coworkers or pals. As a result, it is vital to maintain a constant interest in their mental and emotional health, therefore therapy approaches could be adapted in this regard, while keeping in mind that work and family are interlinked domains that can be influenced by each other.

\section{Limitations and future studies}

The current study, however, has certain limitations. One of the study's limitations is that self-reporting instruments

\section{REFERENCES}

Abendroth, A.-K., \& Reimann, M. (2018). Chapter 15 Telework and Work-Family Conflict across Workplaces: Investigating the Implications of Work-Family-Supportive and High-Demand Workplace Cultures. Contemporary Perspectives in Family Research, 323-348. https://doi.org/10.1108/s1530-353520180000013017

Ahorsu, D. K., Lin, C.-Y., Imani, V., Saffari, M., Griffiths, M. D., \& Pakpour, A. H. (2020). The Fear of COVID-19 Scale: Development and Initial Validation. International Journal of Mental Health and Addiction. https://doi.org/10.1007/s11469-020-00270-8

Alyami, M., de Albuquerque, J. V., Krägeloh, C. U., Alyami, H., \& Henning, M. A. (2021). Effects of Fear of COVID-19 on Mental Well-Being and Quality of Life among Saudi Adults: A Path Analysis. Saudi Journal of Medicine and Medical Sciences, 9(1), 24. were used, which are regarded subjective because respondents may not be able to appropriately assess themselves.

Another limitation of the study could be the fact that the dependent variable, work-family conflict, was investigated as a unitary whole, so it was not analyzed multilaterally, from the perspective of its bidirectional meaning (work-family and family-work ), as well as from the perspective of the subdimensions of the construct (time, role demands, behavior). It is very possible that the factors that determine one type of conflict will not determine the other, and therefore it would be important for future research to include a comprehensive analysis in this regard. At the same time, it would have been useful to investigate several aspects related to family life, such as the support from the partner, the existence of child caregivers and so on. Moreover, the generalization of the results could be limited, because all participants come from the same culture, ie a rather collectivist culture, and according to Hofstede (2011) in this type of society, employer/employee interactions are perceived from the point of view of their morality (almost like a family connection). In the future, a comparative, cross-cultural study will be attempted, as it may present a different picture of the relationships between the investigated variables. Among the limitations, it can be counted that, although all participants stated that they had children, the age of the children was not taken into account for this study, and moreover, the single parents were not asked whether or not they live with the child. These issues are essential in investigating family relationships and responsabilities that may influence work, but they will be considered in future studies.

Ashforth, B. E., Kreiner, G. E., \& Fugate, M. (2000). All in a Day'S Work: Boundaries and Micro Role Transitions. Academy of Management Review, 25(3), 472-491. https://doi.org/10.5465/amr.2000.3363315

Bakker, A. B., \& Demerouti, E. (2007). The Job DemandsResources model: state of the art. Journal of Managerial Psychology, 22(3), 309-328. https://doi.org/10.1108/02683940710733115

Bakker, A. B., \& Demerouti, E. (2014). Job DemandsResources Theory. Wellbeing, 1-28. https://doi.org/10.1002/9781118539415.wbwell019

Bakker, A. B., Demerouti, E., \& Euwema, M. C. (2005). Job Resources Buffer the Impact of Job Demands on Burnout. Journal of Occupational Health Psychology, 10(2), 170-180. https://doi.org/10.1037/1076-8998.10.2.170 
Bakker, A. B., ten Brummelhuis, L. L., Prins, J. T., \& der Heijden, F. M. M. A. (2011). Applying the job demandsresources model to the work-home interface: A study among medical residents and their partners. Journal of Vocational Behavior, 79(1), 170-180. https://doi.org/10.1016/j.jvb.2010.12.004

Bakker, A. B., ten Brummelhuis, L. L., Prins, J. T., \& der Heijden, F. M. M. A. (2011). Applying the job demandsresources model to the work-home interface: A study among medical residents and their partners. Journal of Vocational Behavior, 79(1), 170-180. https://doi.org/10.1016/j.jvb.2010.12.004

Bakker, A. B., Van Emmerik, H., \& Van Riet, P. (2008). How job demands, resources, and burnout predict objective performance: A constructive replication. Anxiety, Stress \& Coping, 21(3), 309-324. https://doi.org/10.1080/10615800801958637

Balogun, A. G., Afolabi, O. A., \& Ibini, O. D. (2020). Job Demands as Mediators between Work Engagement and Work-family Conflict. Nigerian Journal of Psychological Research.

Berdicchia, D., \& Masino, G. (2019). The Ambivalent Effects of Participation on Performance and Job Stressors: The Role of Job Crafting and Autonomy. Human Performance, 32(5),

https://doi.org/10.1080/08959285.2019.1669038

Bowling, N. A., \& Kirkendall, C. (2012). Workload: A Review of Causes, Consequences, and Potential Interventions. Contemporary Occupational Health Psychology, 221-238. https://doi.org/10.1002/9781119942849.ch13

Bowling, N. A., Alarcon, G. M., Bragg, C. B., \& Hartman, M. J. (2015). A meta-analytic examination of the potential correlates and consequences of workload. Work \& Stress, 29(2), 95-113.

https://doi.org/10.1080/02678373.2015.1033037

Brauchli, R., Bauer, G. F., \& Hämmig, O. (2014). Job Autonomy Buffers the Impact of Work-Life Conflict on Organizational Outcomes. Swiss Journal of Psychology, 73(2), 77-86. https://doi.org/10.1024/1421-0185/a000126

Campione, W. (2008). Employed Women's Well-Being: The Global and Daily Impact of Work. Journal of Family and Economic Issues, 29(3), 346-361. https://doi.org/10.1007/s10834-008-9107-x

Clark, S. C. (2000). Work/Family Border Theory: A New Theory of Work/Family Balance. Human Relations, 53(6), 747-770. https://doi.org/10.1177/0018726700536001

Coelho, C. M., Suttiwan, P., Arato, N., \& Zsido, A. N. (2020). On the Nature of Fear and Anxiety Triggered by COVID-19. Frontiers in Psychology, 11. https://doi.org/10.3389/fpsyg.2020.581314

Cooklin, A. R., Westrupp, E., Strazdins, L., Giallo, R., Martin, A., \& Nicholson, J. M. (2014). Mothers' work-family conflict and enrichment: associations with parenting quality and couple relationship. Child: Care, Health and Development, 41(2), 266-277. https://doi.org/10.1111/cch.12137

Davy, J. A., Kiniki, A. J., \& Scheck, C. L. (1997). A test of job security's direct and mediated effects on withdrawal cognitions. Journal of Organizational Behavior, 18(4), 323$349 . \quad$ https://doi.org/10.1002/(sici)10991379(199707)18:4<323::aid-job801>3.0.c0;2-\#

De Witte, H. (1999). Job Insecurity and Psychological Wellbeing: Review of the Literature and Exploration of Some Unresolved Issues. European Journal of Work and Organizational Psychology, 8(2), 155-177. https://doi.org/10.1080/135943299398302

De Witte, H. (2000). Arbeidsethos en jobonzekerheid: Meting en gevolgen voor welzijn, tevredenheid en inzet op het werk [Work ethic and job insecurity: Measurement and consequences for well-being, satisfaction and productivity]. R. Bouwen, K. De Witte, H. De Witte, \& T. Taillieu (Eds.), Van Groep Naar Gemeenschap. Liber Amicorum Prof. Dr Leo Lagrou.

De Witte, H., De Cuyper, N., Handaja, Y., Sverke, M., Näswall, K., \& Hellgren, J. (2010). Associations Between Quantitative and Qualitative Job Insecurity and Well-Being. International Studies of Management \& Organization, 40(1), 40-56. https://doi.org/10.2753/imo0020-8825400103

Delanoeije, J., \& Verbruggen, M. (2020). Between-person and within-person effects of telework: a quasi-field experiment. European Journal of Work and Organizational Psychology, 29(6), 795-808. https://doi.org/10.1080/1359432x.2020.1774557

Demerouti, E., Bakker, A. B., Nachreiner, F., \& Schaufeli, W. B. (2001). The job demands-resources model of burnout. Journal of Applied Psychology, 86(3), 499-512. https://doi.org/10.1037/0021-9010.86.3.499

Demerouti, E., Bouwman, K., \& Sanz-Vergel, A. I. (2011). Job Resources Buffer the Impact of Work-Family Conflict on Absenteeism in Female Employees. Journal of Personnel Psychology, 10(4), 166-176. https://doi.org/10.1027/18665888/a000044

Derks, D., van Duin, D., Tims, M., \& Bakker, A. B. (2014). Smartphone use and work-home interference: The moderating role of social norms and employee work engagement. Journal of Occupational and Organizational Psychology, $\quad 88(1), \quad 155-177$. https://doi.org/10.1111/joop.12083

Dijst, M. (2004). ICTs and Accessibility: An Action Space Perspective on the Impact of New Information and Communication Technologies. Advances in Spatial Science, 27-46. https://doi.org/10.1007/978-3-540-24827-9_3

Dingel, J. I., \& Neiman, B. (2020). How many jobs can be done at home? Journal of Public Economics, 189, 104235. https://doi.org/10.1016/j.jpubeco.2020.104235

Duxbury, L., Higgins, C., \& Lee, C. (1994). Work-Family Conflict: A Comparison by Gender, Family Type, and 
Perceived Control. Journal of Family Issues, 15(3), 449466. https://doi.org/10.1177/019251394015003006

Eddleston, K. A., \& Mulki, J. (2017). Toward Understanding Remote Workers' Management of Work-Family Boundaries: The Complexity of Workplace Embeddedness. Group \& Organization Management, 42(3). https://doi.org/10.1177/1059601115619548

Edwards, J. R., \& Rothbard, N. P. (2000). Mechanisms Linking Work and Family: Clarifying the Relationship between Work and Family Constructs. The Academy of Management Review, 25(1), 178. https://doi.org/10.2307/259269

Engelhard, I. M., van Uijen, S. L., van Seters, N., \& Velu, N. (2015). The Effects of Safety Behavior Directed Towards a Safety Cue on Perceptions of Threat. Behavior Therapy, 46(5), 604-610. https://doi.org/10.1016/j.beth.2014.12.006 Flint, E., Bartley, M., Shelton, N., \& Sacker, A. (2013). Do labour market status transitions predict changes in psychological well-being? Journal of Epidemiology and Community Health, 67(9), 796-802. https://doi.org/10.1136/jech-2013-202425

Gadeyne, N., Verbruggen, M., Delanoeije, J., \& De Cooman, R. (2018). All wired, all tired? Work-related ICT-use outside work hours and work-to-home conflict: The role of integration preference, integration norms and work demands. Journal of Vocational Behavior, 107, 86-99. https://doi.org/10.1016/j.jvb.2018.03.008

Gilboa, S., Shirom, A., Fried, Y., \& Cooper, C. (2008). A meta-analysis of work demand stressors and job performance: examining main and moderating effects. Personnel Psychology, 61(2), 227-271. https://doi.org/10.1111/j.1744-6570.2008.00113.x

Glavin, P., \& Schieman, S. (2012). Work-Family Role Blurring and Work-Family Conflict. Work and Occupations, 39(1), 71-98. https://doi.org/10.1177/0730888411406295

Grant, C. A., Wallace, L. M., Spurgeon, P. C., Tramontano, C., \& Charalampous, M. (2019). Construction and initial validation of the E-Work Life Scale to measure remote eworking. Employee Relations, 41(1), 16-33. https://doi.org/10.1108/er-09-2017-0229

Greenhaus, J. H., \& Beutell, N. J. (1985). Sources of Conflict between Work and Family Roles. The Academy of Management Review, 10(1), 76. https://doi.org/10.2307/258214

Greenhaus, J. H., Parasuraman, S., Granrose, C. S., Rabinowitz, S., \& Beutell, N. J. (1989). Sources of workfamily conflict among two-career couples. Journal of Vocational Behavior, 34(2), 133-153. https://doi.org/10.1016/0001-8791(89)90010-9

Gregory, A., \& Milner, S. (2009). Work-life Balance: A Matter of Choice? Gender, Work \& Organization, 16(1), 1-13. https://doi.org/10.1111/j.1468-0432.2008.00429.x

Hackman, J. R., \& Oldham, G. R. (1976). Motivation through the design of work: test of a theory. Organizational Behavior and Human Performance, 16(2), 250-279. https://doi.org/10.1016/0030-5073(76)90016-7

Hamouche, S. (2020). COVID-19 and employees' mental health: stressors, moderators and agenda for organizational actions. Emerald Open Research, 2, 15. https://doi.org/10.35241/emeraldopenres.13550.1

Han, K.-M., Shin, C., Yoon, H.-K., Ko, Y.-H., Kim, Y.-K., \& Han, C. (2018). Emotional labor and depressive mood in service and sales workers: Interactions with gender and job autonomy. Psychiatry Research, 267, 490-498. https://doi.org/10.1016/j.psychres.2018.06.044

Haslam, D., Filus, A., Morawska, A., Sanders, M. R., \& Fletcher, R. (2014). The Work-Conflict Scale (WAFCS): Development and Initial Validation of a Self-report Measure of Work-Family Conflict for Use with Parents. Child Psychiatry \& Human Development, 46(3), 346-357. https://doi.org/10.1007/s10578-014-0476-0

Hofstede, G. J. (2017). Hofstede Insights Organizational Culture Consulting. Hofstede Insights. https://www.hofstede-insights.com/.

Höge, T., Sora, B., Weber, W. G., Peiró, J. M., \& Caballer, A. (2015). Job insecurity, worries about the future, and somatic complaints in two economic and cultural contexts: A study in Spain and Austria. International Journal of Stress Management, 22(3), 223-242. https://doi.org/10.1037/a0039164

IFC Survey Reveals Extent of COVID-19 Pandemic's Impact on Global Trade Finance. International Finance Corporation. (2020).

https://pressroom.ifc.org/all/pages/PressDetail.aspx?ID=26 279.

Inoue, A., Kawakami, N., Eguchi, H., \& Tsutsumi, A. (2018). Interaction effect of job insecurity and role ambiguity on psychological distress in Japanese employees: a crosssectional study. International Archives of Occupational and Environmental Health, 91(4), 391-402. https://doi.org/10.1007/s00420-018-1288-5

Jiang, L., \& Probst, T. M. (2016). A multilevel examination of affective job insecurity climate on safety outcomes. Journal of Occupational Health Psychology, 21(3), 366-377. https://doi.org/10.1037/ocp0000014

Kaduk, A., Genadek, K., Kelly, E. L., \& Moen, P. (2019). Involuntary vs. voluntary flexible work: insights for scholars and stakeholders. Community, Work \& Family, 22(4), 412442. https://doi.org/10.1080/13668803.2019.1616532

Kahn, R. L., Wolfe, D. M., Quinn, R. P., Snoek, J. D., \& Rosenthal, R. A. (1964). Organizational Stress: Studies in Role Conflict and Ambiguity. American Journal of Sociology, 71(1), 103-104. https://doi.org/10.1086/224004

Kazekami, S. (2020). Mechanisms to improve labor productivity by performing telework. Telecommunications Policy, $\quad$ 44(2), 101868. https://doi.org/10.1016/j.telpol.2019.101868 
Keim, A. C., Landis, R. S., Pierce, C. A., \& Earnest, D. R. (2014). Why do employees worry about their jobs? A metaanalytic review of predictors of job insecurity. Journal of Occupational Health Psychology, 19(3), 269-290. https://doi.org/10.1037/a0036743

Keim, A. C., Landis, R. S., Pierce, C. A., \& Earnest, D. R. (2014). Why do employees worry about their jobs? A metaanalytic review of predictors of job insecurity. Journal of Occupational Health Psychology, 19(3), 269-290. https://doi.org/10.1037/a0036743

Kim, T. J., \& von dem Knesebeck, O. (2015). Is an insecure job better for health than having no job at all? A systematic review of studies investigating the health-related risks of both job insecurity and unemployment. BMC Public Health, 15(1). https://doi.org/10.1186/s12889-015-2313-1

Korunka, C., \& Kubicek, B. (2017). Job Demands in a Changing World of Work. https://doi.org/10.1007/978-3-31954678-0_1

Lin, C.-Y. (2020). Social reaction toward the 2019 novel coronavirus (COVID-19). Social Health and Behavior, 3(1), 1. https://doi.org/10.4103/shb.shb_11_20

Lu, J. G., Brockner, J., Vardi, Y., \& Weitz, E. (2017). The dark side of experiencing job autonomy: Unethical behavior. Journal of Experimental Social Psychology, 73, 222-234. https://doi.org/10.1016/j.jesp.2017.05.007

Menaghan, E. G. (1991). Work Experiences and Family Interaction Processes: The Long Reach of the Job? Annual Review of Sociology, 17(1), 419-444. https://doi.org/10.1146/annurev.so.17.080191.002223

Mertens, G., Gerritsen, L., Duijndam, S., Salemink, E., \& Engelhard, I. M. (2020). Fear of the coronavirus (COVID19): Predictors in an online study conducted in March 2020. Journal of Anxiety Disorders, 74, 102258. https://doi.org/10.1016/j.janxdis.2020.102258

Mirchandani, K. (2000). "The Best of Both Worlds" and "Cutting My Own Throat": Contradictory Images of HomeBased Work. Qualitative Sociology, 23(2), 159-182. https://doi.org/10.1023/a:1005448415689

Mohr, G. B. (2000). The changing significance of different stressors after the announcement of bankruptcy: a longitudinal investigation with special emphasis on job insecurity. Journal of Organizational Behavior, 21(3), 337359.

https://doi.org/10.1002/(sici)1099-

1379(200005)21:3<337::aid-job18>3.0.c0;2-g

Mokhtarian, P. L., \& Salomon, I. (1997). Emerging travel patterns: Do telecommunications make a difference?

Molina, J. A. (2020). The Work-Family Conflict: Evidence from the Recent Decade and Lines of Future Research. Journal of Family and Economic Issues. https://doi.org/10.1007/s10834-020-09700-0

Moore, J. (2006). Homeworking and work-life balance: does it add to quality of life? European Review of Applied Psychology, 56(1), 5-13. https://doi.org/10.1016/j.erap.2005.02.013
Morris, J. A., \& Feldman, D. C. (1996). The Dimensions, Antecedents, and Consequences of Emotional Labor. The Academy of Management Review, 21(4), 986. https://doi.org/10.2307/259161

Nahrgang, J. D., Morgeson, F. P., \& Hofmann, D. A. (2011). Safety at work: A meta-analytic investigation of the link between job demands, job resources, burnout, engagement, and safety outcomes. Journal of Applied Psychology, 96(1), 71-94. https://doi.org/10.1037/a0021484

Nauman, S., Zheng, C., \& Naseer, S. (2020). Job insecurity and work-family conflict. International Journal of Conflict Management, 31(5), 729-751. https://doi.org/10.1108/ijcma-09-2019-0159

Nicola, M., Alsafi, Z., Sohrabi, C., Kerwan, A., Al-Jabir, A., Iosifidis, C., Agha, M., \& Agha, R. (2020). The socioeconomic implications of the coronavirus pandemic (COVID19): A review. International Journal of Surgery, 78, 185-193. https://doi.org/10.1016/j.jisu.2020.04.018

Nilles, J. M., Carlson, F. R., Gray, P., \& Hanneman, G. (1976). Telecommuting - An Alternative to Urban Transportation Congestion. IEEE Transactions on Systems, Man, and Cybernetics, SMC-6(2), 77-84. https://doi.org/10.1109/tsmc.1976.5409177

Pappas, G., Kiriaze, I. J., Giannakis, P., \& Falagas, M. E. (2009). Psychosocial consequences of infectious diseases. Clinical Microbiology and Infection, 15(8), 743-747. https://doi.org/10.1111/j.1469-0691.2009.02947.x

Purwanto, A., Asbari, M., Fahlevi, M., Mufid, A., Agistiawati, E., Cahyono, Y., \& Suryani, P. (2020). Impact of Work From Home (WFH) on Indonesian teachers performance during the Covid-19 pandemic: An exploratory study. International Journal of Advanced Science and Technology, 29(5).

Roe, R., \& Zijlstra, F. (2000). Work pressure. Results of a conceptual and empirical analysis. Hogrefe \& Huber Publishers.

https://www.researchgate.net/publication/230627007_Work _pressure_Results_of_a_conceptual_and_empirical_analy sis

Schaufeli, W. B., \& Bakker, A. B. (2004). Job demands, job resources, and their relationship with burnout and engagement: a multi-sample study. Journal of Organizational Behavior, 25(3), 293-315. https://doi.org/10.1002/job.248

Seery, B. L., Corrigall, E. A., \& Harpel, T. (2008). JobRelated Emotional Labor and Its Relationship to WorkFamily Conflict and Facilitation. Journal of Family and Economic Issues, 29(3), 461-477. https://doi.org/10.1007/s10834-008-9116-9

Spurk, D., \& Straub, C. (2020). Flexible employment relationships and careers in times of the COVID-19 pandemic. Journal of Vocational Behavior, 119, 103435. https://doi.org/10.1016/j.jvb.2020.103435

Sverke, M., Hellgren, J., \& Näswall, K. (2002). No security: A meta-analysis and review of job insecurity and its 
consequences. Journal of Occupational Health Psychology, 7(3), 242-264. https://doi.org/10.1037/1076-8998.7.3.242 Tay, L., Kuykendall, L., \& Diener, E. (2015). Satisfaction and Happiness - The Bright Side of Quality of Life. Global Handbook of Quality of Life, 839-853. https://doi.org/10.1007/978-94-017-9178-6_39

Teo, J. (2020). More Working from Home Feel Stressed Than Those on Covid-19 Front Line: Survey. The Straits Times.

https://www.straitstimes.com/singapore/health/more-workfrom-homers-feel-stressed-than-front-line-workers-

singapore-survey-on.

Vander Elst, T., Näswall, K., Bernhard-Oettel, C., De Witte, H., \& Sverke, M. (2016). The effect of job insecurity on employee health complaints: A within-person analysis of the explanatory role of threats to the manifest and latent benefits of work. Journal of Occupational Health Psychology, 21(1), 65-76. https://doi.org/10.1037/a0039140

Vyas, L., \& Butakhieo, N. (2020). The impact of working from home during COVID-19 on work and life domains: an exploratory study on Hong Kong. Policy Design and Practice, 1-18.
Wall, T. D., Kemp, N. J., Jackson, P. R., \& Clegg, C. W. (1986). Outcomes of Autonomous Workgroups: A LongTerm Field Experiment. Academy of Management Journal, 29(2), 280-304. https://doi.org/10.5465/256189

Wang, H.jiang, Lu, C.-qin, \& Siu, O.-ling. (2015). Job insecurity and job performance: The moderating role of organizational justice and the mediating role of work engagement. Journal of Applied Psychology, 100(4), 12491258. https://doi.org/10.1037/a0038330

Xanthopoulou, D., Bakker, A. B., Demerouti, E., \& Schaufeli, W. B. (2009). Work engagement and financial returns: A diary study on the role of job and personal resources. Journal of Occupational and Organizational Psychology, 82(1), 183-200. https://doi.org/10.1348/096317908x285633 Zhou, X., Snoswell, C. L., Harding, L. E., Bambling, M., Edirippulige, S., Bai, X., \& Smith, A. C. (2020). The Role of Telehealth in Reducing the Mental Health Burden from COVID-19. Telemedicine and e-Health, 26(4), 377-379. https://doi.org/10.1089/tmj.2020.0068

Ünsar, S. A. (2011). Effect of motivation on severance tendency: a field research. J. Acad. Sight.

https://doi.org/10.1080/25741292.2020.1863560 